\title{
Attached: The Object and the Collective
}

\section{Cultural Techniques in 1983, 2000, 2020}

As one of the reports written in the course of Friedrich Kittler's Habilitation procedure attests, in 1983 in the context of the humanities, the term "cultural techniques" carried the stigma of being unscientific. Kittler's Aufschreibesysteme 1800/1900 (1985, translated as Discourse Networks 1800/1900) was regarded as belonging to a type of book that might be labeled "kulturtechnisch," which included other works such as Hans-Dieter Bahr's Über den Umgang mit Maschinen (1983, “On interacting with machines”), Jean Baudrillard's L'Échange symbolique et la mort (1976, Symbolic Exchange and Death), Oskar Negt and Alexander Kluge's Geschichte und Eigensinn (1981, History and Obstinacy), Wolfgang Schivelbusch's Geschichte der künstlichen Helligkeit im 19. Jahrhundert (1983, Disenchanted Night: The Industrialization of Light in the Nineteenth Century), or Jacques Derrida's La carte postale (1980, The Post Card). What these books have in common (if nothing else) is that they appear to suspend "the proven foundations of scientific knowledge." 1 Kittler himself had made use of the term "cultural techniques" at the end of the summer of 1983 in the preface he was pressured to write (which was later suppressed) for Aufschreibesysteme 1800/1900. "Even écriture, which has in the meantime become a hermeneutic slogan, does not use the term 'cultural techniques' to mean cultural techniques."2 Describing reading and writing as cultural techniques meant, for Kittler (at that time), first, treating reading and writing as techniques for steering and programming people who could never be "mere individuals." Referring to Marcel Mauss's "techniques of the body," ${ }^{3}$ Kittler argues that an "approach concerned with cultural techniques" strips "even the most quotidian of practices of their apparent harmlessness ... since they suddenly became transparent as expressions of state or individual programs." "Cultural tech-

1 Wolfram Mauser, "Gutachten über die Habilitationsschrift von Friedrich A. Kittler: Aufschreibesysteme 1800/1900,” Zeitschrift für Medienwissenschaft 6, 1 (2012): 169-197, here 169.

2 Friedrich Kittler, “ Aufschreibesysteme 1800/1900: Vorwort," Zeitschrift für Medienwissenschaft 6, 1 (2012): 117-126, here 125.

3 Marcel Mauss, “Techniques of the Body," trans. Ben Brewster, Economy and Society 2, 1 (1973 [1934]): 70-88.

4 Kittler, "Vorwort," 126.

Translated by Michael Thomas Taylor

Ә Open Access. (C) 2020 Bernhard Siegert, published by De Gruyter. @BY This work is licensed under a Creative Commons Attribution 4.0 International License.

https://doi.org/10.1515/9783110647044-008 
niques" was thus the term that allowed Kittler, in the early eighties, to formulate the scandalous idea that poetry was functionalized by the state into a control loop from 1800 onwards - for the training of education officials. Hence the concept of cultural techniques began to circulate, on the one hand, in the context of reinterpreting literary history as part of a history of data processing and, on the other hand, in order to brand the (as yet nameless) discourse of a media-theoretical and media-historical materialism with the stigma of being unscientific.

Together with the preface to Discourse Networks, the term "cultural technique" then disappeared from Kittler's conceptual repertoire for the next twenty years. “Technical media” took its place, only to again make way for cultural techniques with the founding of the Hermann von Helmholtz Centre for Cultural Techniques at the Humboldt-Universität zu Berlin. Instead of Grammophone - Film - Typewriter (1999 [1986]), the focus was now on “image - writing - number” (a somewhat strange triad that seems to imply numbers are not also writing). What does this double exchange of positions mean? Will "media theory" (at least in its Kittlerian vein) prove to have been but a brief interlude in the history of how research into cultural techniques was established as an academic field of study? Or was it necessary, after 1983, to replace the concept of cultural techniques with the concept of media in order to free the term "cultural techniques" from being deemed the epitome of all the subversive powers threatening the discursive sovereignty of the humanities? The latter seems more likely. This makes it all the more important to bear in mind that if, in 1983, the concept of cultural techniques was intended to decouple literature (or philosophy or art) from the individual (or from spirit or style) in order for literature to be described as a system of data processing, then today's research into cultural techniques must strictly de-individualize the practices on which it focuses, even if the concept of "discourse networks" has since become too narrow. Despite the general trend toward border crossing between media and social theory, this would require us to note crucial doubts about the use of the concept of cultural techniques in empirical media research, such that practices would again be viewed as originating in presuppositionless individuals.

Today, thirty-five years after the appearance of the term "cultural techniques" in the preface Kittler was compelled to write, a conference topic such as "Cultural Techniques of the Collective" makes it clear that the thrust of the concept and thus also its potential to cause controversy have changed and multiplied. The question of the cultural techniques of the collective would have to interrogate, first and foremost, formations of community with respect to those conditions that are not accessible to the community itself. These techniques would include, for example, the cultural technique of eating, inasmuch as eating, in contrast to food intake, engenders community. The question of which cultural programs determine our eating practices points to the cultural technique of sacrifice and this, in turn, points to the cultural 
technique of domesticating animals (because only the domesticated animal can be sacrificed). ${ }^{5}$ An understanding of cultural techniques of the collective in the sense of cultural techniques of various collectives, on the other hand, would be a misunderstanding of the term cultural technique, insofar as such an understanding reconnects practices to a subject, to a collective subject, instead of to a program. The discourse of cultural techniques, however, has always aimed at hybrid collectives, that is, at collectives of subjects and objects or of quasi-subjects and quasi-objects. A view of the collective as a subject would therefore be antithetical to the basic concept of research into cultural techniques.

Cultural techniques of the collective are situated on much more primitive level than cultural techniques of reading and writing. They concern culturalarchaeological processes describing culture in layers far below the discourses of pedagogy, the university, and techniques of reading and writing. In contrast to 1983 and 2000, cultural techniques in 2020 are not only practices that create symbolic orders by preceding the concepts derived from them (such as image, text, number). On a level located below such complex practices as reading, writing, arithmetic, or drawing, etc., the concept of cultural techniques concerns the primary process of articulation as such. While it is undoubtedly true that reading, writing, arithmetic, and drawing are elementary cultural techniques, and that these cultural techniques consist of recursive operational chains that combine processes of hominization with higher media functions such as storage, transmission, and calculation, it is also indisputable that these practices rest, as semiotic practices, on a culturally primary process of articulation distinguishing signal and noise, message and medium, form and matter, communication and cacography, figure and ground. ${ }^{6}$ With the second turn toward cultural techniques in German-language media theory that occurred

5 See Walter Burkert, Homo Necans: Interpretationen altgriechischer Opferriten und Mythen (Berlin and New York: De Gruyter, 1972), 53-55; Thomas Macho, “Tier," in Vom Menschen: Handbuch Historische Anthropologie, ed. Christoph Wulf (Weinheim: Beltz, 1997), 73-75.

6 Friedrich Kittler can be assumed to have understood media as cultural techniques, insofar as he considered it possible to analyze all individual media (from papyrus scrolls to the post office or up to the computer) as a more or less complex chain of the three functions of storage, transmission, and processing; see Friedrich Kittler, "Geschichte der Kommunikationsmedien," in On Line: Kunst im Netz (Graz: Steirische Kulturinitiative, 1993), 66-81; on this point, see also Sybille Krämer, "The Cultural Techniques of Time Axis Manipulation: On Friedrich Kittler's Conception of Media," Theory, Culture and Society 23, 7-8 (2006): 93-109. However, Kittler saw storage, transmission, and processing as media functions resting on a triad, postulated a priori of data, addresses, and commands, and he showed little interest in the processes of primary cultural techniques through which data, addresses, and commands were articulated in the first place. 
at the end of the twentieth century, these "elementary cultural techniques" of reading, writing, arithmetic, and image making were joined by a series of further operations that might be called "primitive cultural techniques": drawing a line, filtering or sifting, separating land and sea from one another, measuring a field, erecting an enclosure, or sacrificing an animal. Primitive cultural techniques are used to process distinctions relevant to a concept of culture without reducing it to alphanumeric $\operatorname{codes}^{7}$ (such as distinctions like those between inside and outside, pure and impure, human and animal, sacred and profane, etc.). ${ }^{8}$ Whereas the production, processing, and deconstruction of the difference between male and female had been an essential characteristic of discursive systems, the concept of cultural techniques includes the articulation, processing, and deconstruction of distinctions that can hardly be located in the field of techniques for processing symbols.

Research into cultural techniques shifts the focus from ontological distinctions understood as naturally given to the problem of generating and stabilizing these distinctions to begin with. In short: the basic figure of this research is the enfolding of the ontic-ontological difference into the ontic. The being of beings falls under the rule of recursive, medial operational chains, where it is perpetually iterated, thematized, reflected, transformed, and re-mediated. Whereas media history examines what a given culture has been able to store, transmit, and process through the available media and codes, a history of cultural techniques is more concerned with the question of how distinctions that constitute symbolic orders (inside/outside, holy/profane, animal/human, sign/ thing, analogue/digital) are recursively repeated, articulated, represented, and operationalized.

Only at this level of operative ontologies does the concept of cultural techniques gain its current strength. Geoffrey Winthrop-Young gets to the heart of this "philosophical" dimension of the theory of cultural techniques as follows:

The term "cultural techniques" refers to operations that coalesce into entities which are subsequently viewed as the agents or sources running these operations. Procedural chains and connecting techniques give rise to notions and objects that are then endowed with essentialized identities. Underneath our ontological distinctions are constitutive, media-dependent ontic operations that need to be teased out by means of a techno-material deconstruction. To rephrase it in a more philosophical vein: the study of cultural techniques continues in a technologically more informed fashion a philosophical line of ontic-ontological question-

7 See Sybille Krämer and Horst Bredekamp, "Kultur, Technik, Kulturtechnik: Wider die Diskursivierung der Kultur," in Bild - Schrift - Zahl, ed. S.K. and H.B. (Munich: Fink, 2003), 11-22. 8 See Bernhard Siegert, Cultural Techniques: Grids, Filters, Doors, and Other Articulations of the Real, trans. Geoffrey Winthrop-Young (New York: Fordham University Press, 2015), 14. 
ing opened up by Martin Heidegger. If German media theory in the Kittlerian vein focused on the materialities of communication, the study of cultural techniques takes aim at the materialities of ontologization. ${ }^{9}$

The ultimate aim of analyses undertaken by such research into cultural techniques is therefore a shift in the deconstruction of ontological categories to the level of technological materialism. The fact that the deconstruction of ontological distinctions takes place on the level of a (cultural) technical materialism marks an essential caveat against the enthusiasm with which collectivization, distribution, assembly, mixing, and posthumanization are currently in fashion everywhere in post-Actor Network Theories. From the point of view of the theory of cultural techniques, these methodological approaches are limited by the fact that they themselves often exhaust their possibilities in the conception of things as actions processed by networks of human and nonhuman actors. This approach may have an enormous potential to generate consensus across all kinds of disciplines inasmuch as it puts practical knowledge distributed in a network on an equal footing with subject-centered knowledge. The danger exists, however, that this merely replaces a notion of a self-present being with that of a self-present action. In not a few variations of post-ANT, such a romanticism of action can be found in an event in which subject and object, form and matter, passive and active, indistinguishably become one. Technology is transformed into a becoming that can no longer be questioned, except in esoteric formulations. The necessary diagnosis of the present - namely, that technology rules today as physis once did - threatens in posthumanist theories to conceptually dissolve into the self-presence of natural objects, into entelecheia and ousia, in a celebration of the life of things. ${ }^{10}$

9 Geoffrey Winthrop-Young, "The Culture of Cultural Techniques: Conceptual Inertia and the Parasitic Materialities of Ontologization,” Cultural Politics 10, 3 (2014): 376-388, here 387.

10 This becomes clearest in Tim Ingold's contributions to the anthropology of technology, in which a nonhylemorphistic concept of technology remains restricted to craftsmanship, and "making" ultimately becomes a religion of life; see Tim Ingold, "Eight Themes in the Anthropology of Technology," Social Analysis: The International Journal of Social and Cultural Practice 41, 1 (March 1997): 106-138; Tim Ingold, “The Textility of Making," Cambridge Journal of Economics 34 (2010): 91-102. The clear-sightedness of media studies emerges, by contrast, precisely where the supposed actions of nature are revealed to be operations of technology. This does not mean, however, that Tim Ingold's texts have not delivered enormously helpful impulses to research into cultural techniques. 


\section{Quasi-objects: Dispersion, Compression, Attachments}

Hybrid objects play a key role in the theory of cultural techniques. Hybrid objects are assemblages - which means they are couplings to themselves - that possess a specific agency due to the nature of this assemblage and the operations it makes possible. Bruno Latour already identified hybrid objects as quasi-objects in Nous n'avons jamais été modernes (1991, We Have Never Been Modern).${ }^{11}$ Quasi-objects refer to a becoming-collective in which objects and people always already possess and produce each other; the identity of subject and object, sign and thing, figure and ground, message and medium, is discovered only through recursively operative assemblages.

The quasi-object was first introduced by Michel Serres in his book on the parasite (1980). It is telling that the second cultural-techniques turn (after 2000) discovered Serres after Foucault, who was so central for discourse networks (Aufschreibesysteme) and their feedback control-systems of cultural techniques. In Serres's book on the parasite, the quasi-object is an object circulating between subjects (as in the children's game of "button button, who's got the button") that transforms the one to whom it attaches into a subject and all others involved in its circulation into a collective. ${ }^{12}$ The theory of the quasi-object is therefore also a theory of the quasi-subject, since both penetrate each other by possessing each other. In his book on Rome published three years later, Serres uses the story of Romulus's diasparagmos that is told by Livius and Plutarch to reveal the mechanisms by which the collective emerges from the operations and transformations of the quasi-object. ${ }^{13}$

After accomplishing these mortal deeds, Romulus was one day holding an assembly of the people on the Campus Martius near the Goat Swamp to review the army. Suddenly a storm arose with loud claps of thunder, enveloping him in a cloud so dense that it hid him from the view of the people. From then on Romulus was no longer on earth. The Roman people finally recovered from their panic when the turbulence was succeeded by a bright and sunny day. Seeing the king's throne empty, they readily believed the assertion of the senators who had been standing nearby that he had been snatched up on high by the storm. Nevertheless, they remained sorrowful and silent for some time, stricken with fear as if they

11 See Bruno Latour, We Have Never Been Modern, trans. Catherine Porter (Cambridge, MA: Harvard University Press, 1993), 51.

12 See Michel Serres, The Parasite, trans. Lawrence Schehr (Baltimore: Johns Hopkins University Press, 1982 [1980]), 224ff.

13 Michel Serres, Rome: Le livre des fondations (Paris: Grasset, 1983), 126-127; Rome: The First Book of Foundations, trans. Randolph Burks (London: Bloomsbury Academic, 2015), 84. 
had been orphaned. Then, on the initiative of a few, they all decided that Romulus should be hailed as a god, son of a god, king, and father of the city of Rome. With prayers they begged his favor, beseeching him to be willing and propitious toward the Roman people and to protect their descendants forever. ${ }^{14}$

The thunderstorm that hides the king from view appears cum magno fragore. Fragor means not only to crash but also to shatter, burst, break, or crack into pieces. This shattering, the fragment, and the fractal are etymologically closely related to noise. If one can no longer understand the voice of the other, the collective shatters. Noise swallows the voices of those who, as Plutarch reports, have scattered out of fear and who come back to the field of Mars only slowly, after peace and light have returned. ${ }^{15}$ Dispersal, compression: a curve exists between noise and signal indicating the degree of statistical coupling between these individual elements. However, both Livy and Plutarch report an alternative version to this ascension:

I suppose that there were some, even then, who privately claimed that the king had been torn into pieces by the hands of the senators. This rumor also spread, though in enigmatic terms. ${ }^{16}$

The second version explains the first. The religious aspect, the miracle of the ascension, is explained by an archaic ritual at the origin of the political that Serres calls suffrage. The alternative must accordingly not be read as an alternative but as a change of perspective that seeks to uncover the operation underlying the myth. Myth (the disappearance) stands opposed to history (diasparagmos), light to dark. The babble of voices, the fragor, comes together to become one voice: acclamation. And this is how Romulus becomes a God. The patricians surround him and tear him up; they then carry the fragments of his body, hidden under their togas, from the square. The corps morcele (the fragmented body, with Lacan) of the king that is carried away under the robes of the senators becomes the founding object of Rome. Michel Serres reads this event ontologically: "There is no object without a collective, there is no human collective without an object. Rome constructs the object.." ${ }^{17}$ And even more so: "Voici le premier objet" ("Here is the first object"). ${ }^{18}$

14 Livy, The history of Rome 1-5, vol. 1, trans., introduction, and notes Valerie M. Warrior (Indianapolis: Hackett, 2006), 25-26.

15 See Plutarch, Lives 1-11, vol. 1, trans., introduction, and notes Bernadotte Perrin (Cambridge: Harvard University Press, 1967), 176.

16 Livy, The history of Rome, 26. See also Plutarch, Lives, 175: "But some conjectured that the senators, convened in the temple of Vulcan, fell upon him and slew him, then cut his body in pieces, put each a portion into the folds of his robe, and so carried it away."

17 Serres, Rome: Le livre des fondations, 129; Rome: The First Book of Foundations, 86.

18 Serres, Rome: Le livre des fondations, 151; Rome: The First Book of Foundations, 100. 
The first object is that which constitutes itself in the relationships of the group - as a game, a "fetish," or a commodity; conversely, the collective cannot form unless something circulates within it "que j'ai nommé quasi-objet" ("that ... I have called quasi-object"). ${ }^{19}$ These quasi-objects vary: sometimes they are body parts hidden in the fold of a toga; sometimes they are stones; sometimes they are voices. When stones converge, what results is a stoning; when voices are compressed, it is suffrage.$^{20}$ Suffrage in the anthropological and political sense is Serres's name for the operation leading to a substance, concept, or idea. There is no difference between what is stable in the mind, what is stable in the senses, and what is stable in phenomena. All these ontological regions are connected with each other by the operation of suffrage. For Serres, there is no being and no concept of being without operation. There is no substance without the operation of dismemberment, stoning, transformation, and coupling of fragments; substance is atomization and compression, but atomization and compression must also be traced back to concrete cultural techniques (such as those of sacrifice). Philosophy without any connection to the history of cultural techniques is and remains empty theorizing.

The origin of the collective, the founding act of Rome, is always a sacrifice; here, Serres follows René Girard's theory of the scapegoat. For the theory of the hybrid object, however, what is more interesting is how objects and individuals emerge from couplings: "I am a part of my group; I carry in my breast a part of the king's body". ${ }^{21}$ This object "se transsubstantie" ("becomes transsubstantiated"): it becomes stone, becomes a bracelet, becomes a precious stone that patricians wear on their fingers. ${ }^{22}$ The quasi-object is transformed, from thing to sign, but it always retains a reference to the object from which it originates; it always remains a fragment.

19 Serres, Rome: Le livre des fondations, 128; Rome: The First Book of Foundations, 86.

20 On this point, see Michael Cuntz, "Aufklärung über den Fetisch: Latours Konzept des faitiche und seine Verbindung zu Serres' Statuen," in Gegenwart des Fetischs: Dingkonjunktur und Fetischbegriff in der Diskussion, ed. Christine Blättler and Falko Schmieder (Vienna: Turia + Kant, 2014), 76: "What circulates in the collective that assembles together and thereby stabilizes itself are, first and foremost, the stones that serve as projectiles and the scraps of flesh from the sacrificial body that has been torn apart. This is the origin of the quasi-objects and this movement persists in the handling of fetishes and idols."

21 Serres, Rome: Le livre des fondations, 150: "Je suis une part de mon groupe, je porte dans mon sein une part du corps du roi." Rome: The First Book of Foundations, 100.

22 Serres, Rome: Le livre des fondations, 151; Rome: The First Book of Foundations, 100. Serres reads the story of Romulus's diasparagmos together with the story of Tarpeia, who betrayed the Romans to the Sabines and demanded, as a reward, what the Sabines were wearing on their left arm, namely, golden bracelets. After she had opened the city gate to the enemies and demanded her reward, the Sabines "stoned" her by throwing their bracelets and shields upon her. 
Hybrid objects belonging to the family of quasi-objects can now be defined more precisely: they are by no means just any arbitrary things but special things that render recursive, that mark and thematize the transubstantiation of things into signs. Hybrid objects are not symbols in the sense of representing what is absent by something present; rather, hybrid objects embed things within signs.

Objects that embed the body parts of the saint in jewels (instead of representing them with jewels) are reliquaries. A secularized variant of reliquaries are the medallions that Elizabeth I gave to her most important counselors and defenders of the empire. Like miniature reliquaries, they were worn on the body, between one's shirt and one's skin, or they were held in the hand, kissed, and could be opened up. The locket known as the Heneage Jewel shows, on its front side, the portrait of Elizabeth in her formal imperial profile, surrounded by diamonds, rubies, and rock crystal from Burma and other parts of the colonial empire. The reverse side is hidden behind a cover, the outside of which depicts the ark of the Reformed church on a stormy sea and refers to Elizabeth's ecclesiastical authority as the kybernetes of the Ecclesia Anglicana. When the cover is opened, another portrait of Elizabeth appears showing her as a private person - a homage to her as a lady, as the "Astraea, Queen of Beauty" who is exalted in contemporary sonnets by John Davies. Her gaze is met inside the lid by the Tudor rose (Fig. 1). Insofar as the stones symbolized the empire's far-reaching trade relations, the hinge of the medallion connected the political-economic second body of the Empire, now defined also in terms of territory, with the portrait of the queen inside. The sources indicate that Elizabeth had a large number of such medallions, which she kept in a cabinet in her bedroom and showed to selected persons. All of them were wrapped in paper and given names by the queen. They are therefore quasi-objects whose owners directly participate in the intimate first body of the queen and, as a collective, guarantee the stability of English hegemony. The proximity to reliquaries representing the earliest examples of these miniatures follows from the fact that they were kept in ivory boxes covered with protective jewels. ${ }^{23}$ These quasi-objects literally materialize the concept of attachments introduced by Antoine Hennion into Actor Network Theory, which he uses to describe the attachment of subjects to objects and vice versa. ${ }^{24}$ These quasi-objects are literally attached to the quasisubjects, and the quasi-subjects are, conversely, attached to the quasi-objects.

23 See John Murdoch et al. (eds.), The English Miniature (New Haven: Yale University Press, 1981), 73 and 76.

24 See Antoine Hennion, Sophie Maisonneuve, and Émilie Gomart, Figures de l'amateur: Formes, objets, pratiques de l'amour de la musique aujourd'hui (Paris: La documentation Française, 2000). It is in this sense that Ulrich Pfisterer also speaks of their "binding function" with regard to the medallions circulating in Rome during the Renaissance. See also Ulrich Pfist- 


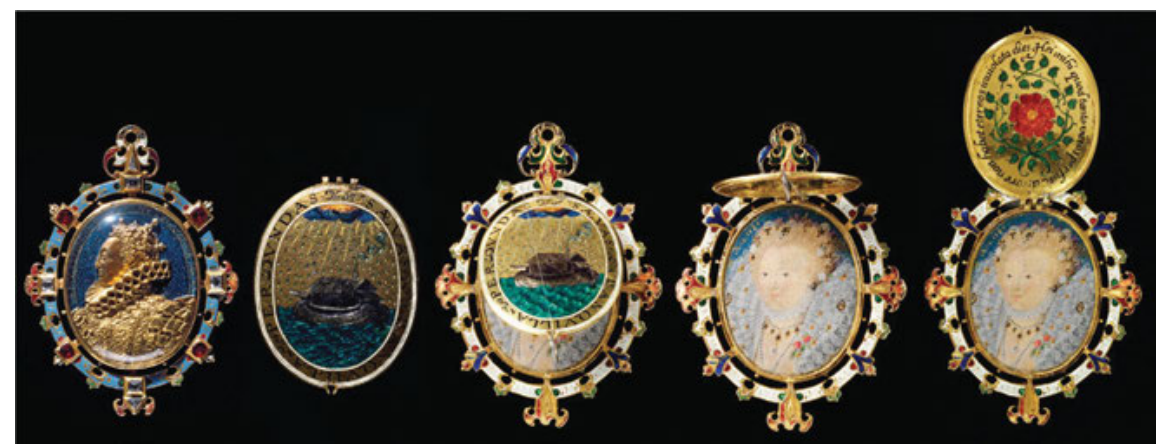

Fig. 1: Nicholas Hilliard, locket known as the Heneage Jewel (or Armada Jewel), ca. 1595, enameled gold, diamonds, Burmese rubies, rock crystal.

Left: front side: Portrait of Queen Elizabeth I; Second from left: reverse side: ark of the Anglican church in stormy sea (lid closed); third from left: half-opened lid; fourth from left: reverse side: portrait of Queen Elizabeth I (lid open $90^{\circ}$ ); right: portrait of Elizabeth I and Tudor Rose (lid fully opened).

What is essential is that the hybrid object's "mode of existence" is engendered by the operations of opening, closing, sewing, coupling, and folding. Signs and things are thus always already entangled by means of linking operations and are part of a continuum of operations that connects assemblages - and that also plugs in the subject attached to these structures.

erer, Lysippus und seine Freunde: Liebesgaben und Gedächtnis im Rom der Renaissance (Berlin: Akademie-Verlag, 2008). 